\title{
NALLD BUSINESS
}

\section{NALLD Resolutions}

FROM time to time NALLD passes resolutions aimed at the improvement of techniques fundamental to the profession. It is our earnest hope that commercial interests can be brought to understand the ideas contained within these resolutions as representative of actual needs voiced by active members of our profession.

At the First Annual Business Meeting held in April, 1966, NALLD passed its first resolution dealing with the necessity of having foreign language tapes accurately timed and explicitly described before using them. While some publishers who produce tapes to accompany texts have very elaborate aids to make them a truly integrated part of the course, it is frequently the case that economic expediency allows taped programs that are greatly lacking to reach the market.

A second resolution was considered at the Second Annual Business Meeting in April, 1967. This would call upon publishers who market tapes to go with their books to conform to a number of quality specifications and options which are highly desirable.

During the Midwestern Regional and Executive Board Meetings in December 1967 the Association will formulate a final draft of these and additional resolutions for inclusion in the agenda of the Third Annual Business Meeting to take place on 25 March 1968, at the Shamrock Hilton Hotel in Houston, Texas. (For a copy of this agenda and information on the Business Meeting and Program address the Secretary of the Association). When any such resolutions are accepted by the membership, they will be published in the following Newsletter and brought to the attention of all pertinent commercial interests.

\section{State Language Laboratory Directories}

To effectively reach the individual language laboratory directors and their administrations in both high schools and colleges, the Association is continuing its project of compiling State Language Laboratory Directories. These Directories will hopefully be instrumental in providing the opportunity for the people directly involved in language laboratory work to communicate on a local level.

Presently there are two editors for each state. One is for the high school directory, and one is for the college directory. Since there are scveral vacancies, anyone with an interest in furthering the profession of language laboratory director in his state is urged to contact NALLD. The work is neither without reward nor overly time consuming, and the benefits to the Association are countless. 
If you feel that you would like a copy of the Directory for your state, or if you are unsure that your school is included in the Directory, write to James W. Dodge, Secretary, NALLD, Brown University, Box E, Providence, R. I., 02912. He will advise you and forward your letter to the Committee on State Directories.

\section{Positions Available}

Institutions searching for language laboratory directors are urged to submit their vacancy descriptions for placement in this portion of the Newsletter. NALLD membership is required; see page one for information.

\section{UNIVERSITY OF CONNECTICUT, Storrs, Ct. 06268}

Contact: Oliver Andrews, Jr., Head, Dept. of Romance and Classical Languages.

Requirements: not specified.

Assignment: Language Laboratory Director; for September 1968.

Salary: From $\$ 9,500$.

Rank: Administrative or to Associate Professor for Ph.D. with publications.

Specifics: New so position dial access remote record laboratory. Necessary expansion authorized.

UNIVERSITY OF NOTRE DAME, Notre Dame, Ind. 46556

Contact: Dr. Robert Nuner, Chairman, Department of Modern Languages.

Requirements: not specified.

Assignment. Half-time Language Laboratory Director, in conjunction with teaching of (in order of preference) Linguistics, Russian, French and Spanish, French or Spanish.

Salary: Open.

Rank: Open.

Specifics: Three 30 position Dage-Bell laboratories (one audio-activerecord and two audio-active). 
UNIVERSITY OF MISSOURI, St. Louis, Mo. 68121

Contact: Enrique Noble, Chairman, Dept. of Modern Languages. 8001 Natural Bridge Road

Requirements: Professional experience.

Assignment: Language Laboratory Director; for September 1968.

Rank: Depending upon qualifications.

Specifics: New equipment installations requires highly qualified Language Laboratory Director for optimal utilization.

\section{Student Personnel Directory}

One of the most frequent personnel duties of any laboratory director is the training of new student assistants. It is the hope of the Association that a directory can be established to list those students who are qualified and experienced in language laboratory work. Thus, freshmen, transfer students or first year graduate students could be referred from institution to institution by consulting their dockets filed with NALLD.

Student membership was approved at the Second Annual Business Meeting, and more information on it and the Student Personnel Directory will be forthcoming in later Newsletters.

\section{NALLD MEETINGS}

MIDWESTERN REGIONAL:

29 December 1967, Conrad Hilton Hotel, Chicago, Ill., 8:45-10:00 AM, Room Three. (With MLA/ACTFL).

\section{SOUTHERN REGIONAL:}

23 February 1968, Jung Hotel, New Orleans, La. (With Southern Conference on Language Teaching). Address the Secretary, NALLD.

THIRD ANNUAL BUSINESS MEETING:

25 March 1968, Shamrock Hilton Hotel, Houston, Texas. (With the DAVI). Address the Secretary, NALLD.

NORTHEASTERN REGIONAL:

5 April 1968, Hotel Americana, New York. (With Northeast Conference on the Teaching of Foreign Languages). Address the Secretary, NALLD. 
As an Affiliate Organization of the American Council on the teaching of Foreign Languages, NALLD has been asked to provide competent specialists to staff a clinic at the First Annual Meeting of ACTFL in Chicago during the last week of December 1967. This clinic, which will cover all phases of language laboratory and audio visual techniques, is an informal drop-in meeting where members of ACTFL can consult with experienced members of our profession. Clinics will be held from 3:00 to 5:00 PM, Wednesday and Thursday, 27-28 December 1967 , in the Sheraton Blackstone, Embassy Room. Clinic coordinators are Louis J. Chatagnier and James W. Dodge. As a service to those who visit these sessions, as well as to the readers of the Newsletter, we offer the following short bibliography.

\section{Bibliograpby}

Ackerman, Thomas J. Language Laboratory Instruction and the Acbievement of First-Year Students of Spanish in Florida. Ph.D. diss. Florida State University 1965.

Allen, Edward D. "The Effects of the Language Laboratory on Development of Skill in a Foreign Language," MLJ, 44 (1960) 8, pp. $355-358$.

"Audio Visual Techniques and the Language Laboratory Bibliography," JEdSoc, (1962) Feb.

Bauer, Eric W. "A Study of the Effectiveness of Two Language Laboratory Conditions in the Teaching of Second Year German," IRAL, 2 (1964) 2, pp. 99-112.

Bourque, Jane M. "Time-Saving Techniques for Lab and Classroom," FR, 37 (1964) 5, pp. 568-574.

Cannaday, Robert W. "Teacher Training and the Language Laboratory," IJAL, 32 (1966) 1, pp. 197-202.

Cannaday, Robert W. and Terry Gamba. Successful Use of the Language Laboratory, Harrisburg, Pennsylvania Department of Public Instruction, 1964-65. A series of eight 15-minute films for modern foreign language teacher training. Accompanied by a detailed Viewer's Guide designed also to serve as a syllabus for workshop and methods course units based on the film series. Film I: Planning for the Language Laboratory; Film II: Basic Language Laboratory Equipment and Its Use; Film III: Language Laboratory; Administration; Film IV: Effective Language Laboratory Practices; Films V \& VI: Language Laboratory Materials; Films VII \& VIII: Testing in the Language Laboratory. Distributed by W.G. O'Connor, 300 North Cameron St., Harrisburg, Penna. 
A Catalogue of the Audio Visual Language Teaching Materials in Repository in the Materials Library of the University of Michigan Language Laboratory. Ann Arbor, Michigan: The University of Michigan 1961. (Publications of the Language Laboratory; a series of Technical Reports).

Donoghue, Mildred R., ed. Foreign Languages and the Scbools: A Book of Readings. Dubuque, Iowa: Brown 1967.

Finn, James D., Donald Perrin and Lee Champion. Studies in the Growth of Instructional Tecbnology, I: Audiovisual Instrumentation for Instruction in the Public Schools, 1930-1960. Occasional Paper No. 6. Washington, National Education Association, Technical Development Project, 1962.

Gaarder, A. Bruce, and Joseph C. Hutchinson. Brief Analysis of the Keating Report. Washington, USOE, 1963.

Guenot, Jean. "Language Laboratories and Still Pictures in Modern Language Teaching," IJAdYEd (1964) 1, pp. 40-46.

Hayes, Alfred S. Language Laboratory Facilities. Technical Guide for the Selection, Purchase, Use, and Maintenance. Washington, USOE, 1963.

Hilton, J. B. The Language Laboratory in Scbool. London: Methuen 1966.

Hocking, Elton. Language Laboratory and Language Learning. Washington, DAVI National Education Association, 1964 (Monograph 2).

Hutchinson, Joseph C. The Language Laboratory . . How Effective Is It? Washington, USOE (OE-27021): originally published in Scbool Life, 47 (1964) Jan-Feb.

Jeanes, R. W., and D. A. Massey. "Language Labs-A New Look," CanMLR, 32 (1966) 2, pp. 40-50.

Kendrick, D. A Bibliograpby for Audio Visual and Language Teaching. London: Audio-Visual Language Association 1965.

Lado, Robert. Language Teaching. A Scientific Approach. New York: McGraw-Hill 1964.

Marty, Fernand. Programming a Basic Foreign Language Course. Roanoke, Va.: Hollins College 1962.

Mathieu, Gustave. "Language Laboratories," RevEdRes, 32 (1962) 2, pp. 168-178. 
Mueller, Theodore M. "Correlating the Language Laboratory with the Textbooks: Some Basic Considerations," IJAL, 29 (1963) 2, pp. 83-89.

Najam, Edward W., ed. "Materials and Techniques for the Language Laboratory," IJAL, 28 (1962), Part II, January. Indiana University Research Center in Anthropology, Folklore, and Linguistics, Publication 18. Bloomington, Indiana: 1962.

Newmark, P. P. "What Language Laboratories Can Do," The Incorporated Linguist, 5 (1966) 2, pp. 42-48.

Probyn, H. E. "The Role of the Monitor in the Language Laboratory," AVLangJ, 3 (1965-66) 3, pp. 137-141.

Quilter, Daniel. Do's and Don't's of Audio-Lingual Teacbing. Waltham, Mass.: Blaisdell 1966.

Schultz, Morton J. The Teacher and Overbead Projection. New York: Prentice Hall, 1965.

Source Materials for Secondary School Teachers of Foreign Languages. Washington, USOE (OE-27001-C).

Spencer, Richard E. "The Influence of Disc or Tape Language Laboratory Equipment on Foreign Language Speaking Test Scores," MLJ, 50 (1966) 4, pp. 207-208.

Stack, Edward M. The Language Laboratory and Modern Language Teaching. New York: Oxford 1966.

Taking the Mystery Out of the Language Laboratory. A Tape-Filmstrip Discussion Course. Available from The 3M Company, St. Paul, Minn.

Valdman, A., ed. Trends in Language Teaching. New York: McGrawHill 1966.

Young, Clarence W., and Charles A. Choquette. An Experimental Study of the Relative Effectiveness of Four Systems of Language Laboratory Equipment in Teaching French Pronunciation. Hamilton, N. Y.: Colgate University 1963. Also, abridged form, "An Experimental Study of the Relative Effectiveness of Four Systems of Equipment for Self-Monitoring in Teaching French Pronunciation," IRAL, 3 (1965) 1, pp. 13-49. 